\title{
PERAN STRATEGIS SISTEM EKONOMI ALTERNATIF BAGI PEMBANGUNAN BANGSA DAN NEGARA
}

\author{
Musta'an \\ Universitas Sahid Surakarta \\ musta'an57@gmail.com
}

\begin{abstract}
The purpose of this study is to see how the strategic role of alternative economic system, in this case is the Islamic economic system for the development of the nation and state of Indonesia. The research method used is by using literacy study. The results obtained that the Islamic economic system as an alternative economic system has been proven with the advancement of sharia banks, although the development is slow, because constrained many things such as minimal capital, regulations that have not reached the real application, human resources, low understanding of the community, maximum, monetary tools used by the state still use interest, limited office network, and services that have not been able to meet the standards as do conventional banks. However, the Islamic economic system has helped in strengthening the economic development of the nation and the country especially when the crisis occurred in 1998 until today.
\end{abstract}

Keywords: strategic role, Islamic economic system, nation and state development

\section{PENDAHULUAN}

Sistem ekonomi yang kita kenal selama ini adalah sistem ekonomi kapitalis dan sistem ekonomi sosialis, dimana kedua sistem ini saling bertolak belakang dalam implementasinya, meskipun sampai saat ini sistem ekonomi yang masih berkembang adalah sistem ekonomi yang kapitalis saja. Kenyataan yang ada sampai saat ini negara dan bangsa Indonesia kita tercinta ini yang memiliki sumber daya alam yang melimpah serta memiliki sumber daya manusia belum dapat menciptakan pembangunan bangsa yang merata yang dapat dirasakan setiap warga negaranya.

Melihat kenyataan itu, berarti sistem ekonomi yang digunakan tentunya sudah baik, tetapi perlu adanya konsep sistem ekonomi alternatif yang mungkin dapat menjadi solusi bagi permasalahan mengenai kesenjangan kemakmuran yang belum merata dan terjadi gap yang sangat tajam antara si miskin dan si kaya. Sistem ekonomi Islam atau syariah dapat dijadikan konsep sistem ekonomi sebagai suatu sistem yang berdiri di antara kedua sistem yang sudah ada sebelumnya (sistem ekonomi Islam) sebagai sistem ekonomi alternatif. Menurut Saidus (1996) agama Islam bukan hanya Agama yang memberikan ajaran-ajaran untuk mempersiapkan manusia bagi kehidupan akhirat atau kehidupan kerohania belaka, tetapi mendorong manusia optimis dengan hidupnya sekarang yang bersifat materiil dan positif. Islam adalah suatu cara hidup, way of life yang membimbing seluruh aspek kehidupan manusia, 2 dan bernuansa universal jika dipahami secara utuh dan totalitas dengan mengamalkan ajarannya, sehingga sadar atau tidak sistem ekonomi akan tumbuh dan berkembang dengan baik bila landasannya bertumpu pada nilai dan prinsip syariah, ketika diimplementasikan dalam aspek bisnis dan transaksi ekonomi.

Ekonomi Islam mengalami kemajuan yang cukup pesat, baik dalam kajian akademis di perguruan tinggi maupun dalam praktek operasional. Dalam bentuk pengajaran, ekonomi Islam telah dikembangkan di 
beberapa universitas baik di negara-negara muslim, maupun di negara-negara barat.

Di Indonesia, perkembangan pembelajaran dan pelaksanaan ekonomi Islam juga telah mengalami kemajuan yang pesat. Pembelajaran tentang ekonomi Islam telah diajarkan di beberapa perguruan tinggi yang menjadi basisnya para pemikir. Perkembangan ekonomi Islam sebagai sistem ekonomi alternatif telah mulai mendapatkan momentum sejak didirikannya Bank Muamalat pada tahun 1992. Berbagai Undang-Undangnya yang mendukung tentang sistem ekonomi tersebut pun mulai dibuat, seperti UU No. 7 Tahun 1992 tentang Perbankan sebagaimana yang telah diubah dalam Undang-undang Nomor 10 Tahun 1998 dan Undang-undang Nomor 23 Tahun 1999.

Oleh karena itu, penelitian ini akan mencoba melihat bagaimana peran strategis dari sistem ekonomi alternatif, dalam hal ini adalah sistem ekonomi Islam bagi pembangunan bangsa dan negara Indonesia.

\section{TUJUAN PENELITIAN}

Tujuan Penelitian ini adalah ingin melihat peran strategis dari sistem ekonomi Islam sebagai sistem ekonomi alternatif bagi pembangunan bangsa dan negara Indonesia.

\section{METODE PENELITIAN}

Metode penelitian dengan menggunakan metode literasi dengan melihat data-data yang mendukung permasalahan penelitian yang dilakukan.

\section{PEMBAHASAN}

\section{Perkembangan Ekonomi Islam}

Ekonomi Syariah adalah usaha atau kegiatan yang dilakukan oleh orang per orang atau kelompok orang atau badan usaha yang berbadan hukum atau tidak berbadan hukum dalam rangka memenuhi kebutuhan yang bersifat komersial dan tidak komersial menurut prinsip syariah (Mardani: 2011). Kemudian pendapat lainnya yang dikemukakan oleh Tho'in (2015), sistem ekonomi Islam adalah suatu konsep sistem ekonomi jalan tengah yang mengambil atau mengadopsi kebaikan-kebaikan dari sistem ekonomi sosialis dan sistem ekonomi kapitalis selama tidak bertentangan dengan syariah.

Dikutip dalam sebuah artikel bahwa, Di Indonesia, praktek ekonomi Islam, khususnya perbankan syariah sudah ada sejak tahun 1992. Diawali dengan berdirinya Bank Muamalat Indonesia (BMI) dan Bank-bank Perkreditan Rakyat Syariah (BPRS).Namun, pada dekade hingga tahun 1998, perkembangan bank syariah boleh dibilang agak lambat. Pasalnya, sebelum terbitnya UU No. 10 Tahun 1998 tentang Perbankan, tidak ada perangkat hukum yang mendukung sistem operasional bank syariah kecuali UU No. 7 Tahun 1992 dan PP No. 72 Tahun 1992.

Ekonomi Syariah adalah Ekonomi yang diatur oleh syariat Islam yaitu Al-Quran, Sunnah, Qiyas, Ijma atau Ijtihad. Adanya ketentuan yang jelas tersebut menjadikan ekonomi syariah menjadi mudah diukur kapasitasnya dan mudah dilaksanakan di negara manapun walaupun yang notabene adalah negara yang mayoritas penduduknya nonmuslim seperti Inggris dan Singapura (Shiddieqy, 2011).

Berdasarkan UU No. 7 Tahun 1992 itu bank syariah dipahami sebagai bank bagi hasil. Selebihnya bank syariah harus tunduk kepada peraturan perbankan umum yang berbasis konvensional. Karenanya manajemen bank-bank syariah cenderung mengadopsi produk-produk perbankan konvensional yang disyariatkan. Dengan variasi produk yang terbatas. Akibatnya tidak semua keperluan masyarakat terakomodasi dan produk yang ada 
tidak kompetitif terhadap semua produk bank konvensional.

Perkembangan sistem ekonomi syariah di Indonesia sendiri belum sebegitu pesat seperti di negara-negara lain, Secara sederhana, perkembangan itu dikelompokkan menjadi perkembangan industri keuangan syariah dan perkembangan ekonomi syariah non keuangan. Industri keuangan syariah relatif dapat dilihat dan diukur perkembangannya melalui data-data keuangan yang ada, sedangkan yang non keuangan perlu penelitian yang lebih dalam untuk mengetahuinya.

Di sektor perbankan, hingga saat ini sudah ada tiga Bank Umum Syariah (BUS), 21 unit usaha syariah bank konvensional, 528 kantor cabang (termasuk Kantor Cabang Pembantu (KCP), Unit Pelayanan Syariah (UPS), dan Kantor Kas (KK), dan 105 Bank Pengkreditan Rakyat Syariah (BPRS). Aset perbankan syariah per Maret 2007 lebih dari Rp. 28 triliun dengan jumlah Dana Pihak Ketiga (DPK) hampir mencapai 22 Triliun. Meskipun asset perbankan syariah baru mencapai 1,63 persen dan dana pihak ketiga yang dihimpun baru mencapai $1,64 \%$ dari total asset perbankan nasional (per Februari 2007), namun pertumbuhannya cukup pesat dan menjanjikan. Diproyeksikan, pada tahun 2008, share industri perbankan syariah diharapkan mencapai 5 persen dari total industri perbankan nasional.

Di sektor pasar modal, produk keuangan syariah seperti reksa dana dan obligasi syariah juga terus meningkat. Sekarang ini terdapat 20 reksa dana syariah dengan jumlah dana kelola 638, 8 miliar rupiah. Jumlah obligasi syariah sekarang ini mencapai 17 buah dengan nilai emisi mencapai 2, 209 triliun rupiah.

Di sektor saham, pada tanggal 3 Juli 2000 BEJ meluncurkan Jakarta Islamic Index
(JII). JII yang merupakan indeks harga saham yang berbasis syariah terdiri dari 30 saham emiten yang dianggap telah memenuhi prinsip-prinsip syariah. Data pada akhir Juni 2005 tercatat nilai kapitalisasi pasar sebesar Rp325, 90 triliun atau 43\% dari total nilai kapitalisasi pasar di BEJ. Sementara itu, volume perdagangan saham JII sebesar 348, 9 juta lembar saham atau $39 \%$ dari total volume perdagangan saham dan nilai perdagangan saham JII sebesar Rp 322, 3 miliar atau 42\% dari total nilai perdagangan saham. Peranan pemerintah yang sangat ditunggu-tunggu oleh pelaku keuangan syariah di Indonesia adalah penerbitan Undang-undang Perbankan Syariah dan Undang-undang Surat Berharga Negara Syariah (SBSN).

Di sektor asuransi, hingga Agustus 2006 ini sudah lebih 30 perusahaan yang menawarkan produk asuransi dan reasuransi syariah. Namun, market share asuransi syariah belum baru sekitar $1 \%$ dari pasar asuransi nasional. Di bidang multifinance pun semakin berkembang dengan meningkatnya minat beberapa perusahaan multifinance dengan pembiayaan secara syariah. Angka-angka ini diharapkan semakin meningkat seiiring dengan meningkatnya permintaan dan tingkat imbalan (rate of return) dari masing-masing produk keuangan syariah.

Di sektor mikro, perkembangannya cukup menggembirakan. Pesatnya perkembangan lembaga keuangan berbasis syariah, sampai-sampai banyak lembaga keuangan konvensional membuka unit-unit syariah (Wardani, 2013). Lembaga keuangan mikro syariah seperti Baitul Mal wat Tamwil terus bertambah, demikian juga dengan aset dan pembiayaan yang disalurkan. Sekarang sedang dikembangkan produk-produk keuangan mikro lain semisal micro insurance dan mungkin micro mutual fund (reksa dana mikro). 
Industri keuangan syariah adalah salah satu bagian dari bangunan ekonomi syariah. Sama halnya dengan ekonomi konvensional, bangunan ekonomi syariah juga mengenal aspek makro maupun mikro ekonomi. Namun, yang lebih penting dari itu adalah bagaimana masyarakat dapat berperilaku ekonomi secara syariah seperti dalam hal perilaku konsumsi, giving behavior (kedermawanan), dan sebagainya. Perilaku bisnis dari para pengusaha Muslim pun termasuk dalam sasaran gerakan ekonomi syariah di Indonesia.

Walau terlihat cukup lambat bahkan cenderung stangnan, namun sisi non keuangan dalam kegiatan ekonomi ini juga semakin berkembang. Hal ini ditandai semakin meningkatnya kesadaran masyarakat terhadap perilaku konsumsi yang islami, tingkat kedermawanan yang semakin meningkat ditandai oleh meningkatnya dana zakat, infaq, waqaf, dan sedekah yang berhasil dihimpun oleh badan dan lembaga pengelola dana-dana tersebut.

\section{Kendala Bank Syariah Sebagai Pintu Masuk Ekonomi Islam}

Banyak tantangan dan permasalahan yang dihadapi dalam perkembangan Bank Syari'ah, terutama berkaitan dengan penerapan suatu sistem perbankan yang baru yang mempunyai sejumlah perbedaan prinsip dari sistem keuntungan yang dominan dan telah berkembang pesat di Indonesia.Permasalahan ini dapat berupa permasalahan yang bersifat operasional perbankan maupun aspek dari lingkungan makro. Beberapa kendala yang dihadapi dalam pengembangan Bank Syari'ah antara lain:

\section{a. Permodalan}

Permasalahan yang senantiasa dihadapi dalam rangka pendirian suatu usaha bank syariah saat ini adalah permodalan. Setiap ide ataupun rencana untuk mendirikan Bank Syari'ah sering tidak dapat terwujud sebagai akibat tidak adanya modal yang cukup untuk pendirian Bank Syari'ah tersebut, walaupun dari sisi niat.

b. Peraturan Perbankan

Peraturan Perbankan yang berlaku belum sepenuhnya mengakomodir operasional Bank Syari'ah mengingat adanya sejumlah perbedaan dalam pelaksanaan operasional Bank Syari'ah dengan Bank Konvensional.Ketentuanketentuan perbankan yang ada kiranya masih perlu disesuaikan agar memenuhi ketentuan syari'ah agar Bank Syari'ah dapat beroperasi secara relatif dan efisien.

c. Sumber Daya Manusia

Pengembangan SDM dibidang Perbankan Syari'ah sangat diperlukan karena keberhasilan pengembangan bank syari'ah pada level mikro sangat ditentukan oleh kualitas manajemen dan tingkat pengetahuan serta ketrampilan pengelola bank. SDM dalam perbankan syari'ah memerlukan persyaratan pengetahuan yang luas dibidang perbankan, memahami implementasi prinsip-prinsip syari'ah dalam praktek perbankan serta mempunyai komitmen kuat untuk menerapkannya secara konsisten.

d. Pemahaman Ummat

Pemahaman dan kepedulian sebagian besar umat mengenai sistem dan prinsip bankan syariah belum tepat, bahkan ada di antara ulama dan cendekiawan muslim sendiri masih belum ada kata sepakat untuk mendukung eksistensi bank syariah. Bahkan masih ada kalangan ulama belum ada ketegasan pendapat terhadap eksistensi bank syariah, sehingga terasa kurang tegas.Hal-hal seperti di atas merupakan kejadian nyata yang selalu dan kerap kali dialami dalam operasional bank Syari'ah sehari-harinya, bahkan mungkin lebih parah dari contoh-contoh di atas. Dari kalangan ulama sendiri sampai saat ini belum ada ketegasan pendapat terhadap keberadaan Bank Syari'ah. 
e. Sosialisasi

Sosialisasi yang telah dilakukan dalam rangka memberikan informasi yang lengkap dan besar mengenai kegiatan usaha perbankan syari'ah kepada masyarakat luas belum dilakukan secara maksimal.

f. Piranti Moneter

Piranti Moneter yang pada saat ini masih mengacu pada sistem bunga sehingga belum bisa memenuhi dan mendukung kebijakan moneter dan kegiatan usaha bank syari'ah. Dengan sistem bunga ini bahkan mayoritas masyarkat bangsa ini justru menjadikannya sebagai suatu kebiasaan yang sesat dan menyesatkan (Wardani, 2015)

g. Jaringan Kantor

Pengembangan jaringan kantor Bank Syari'ah diperlukan dalam rangka perluasan jangkauan pelayanan kepada masyarakat. Disamping itu kurangnya jumlah Bank Syari'ah yang ada juga menghambat perkembangan kerjasama antar Bank Syari'ah.

h. Pelayanan

Dunia perbankan senantiasa tidak terlepas pada masalah persaingan, baik dari sisi margin yang diberikan maupun pelayanan. Dari hasil survei lapangan membuktikan bahwa kualitas pelayanan merupakan peringkat pertama kenapa masyarakat memilih bergabung dengan suatu bank. Menurut Tho'in (2011), bahwa kualitas pelayanan berpusat pada upaya pemenuhan kebutuhan dan keinginan pelanggan serta ketepatan penyampaiannya untuk mengimbangi harapan pelanggan.

Sedangkan jika melihat usia bank syariah saat ini yang masih muda bila dibandingkan dengan bank-bank konvensional, tentunya dalam pelayanan masih banyak kekurangan bila dibandingkan dengan bank konvensional.

\section{Penerapan Bagi Bangsa dan Negara}

Indonesia merupakan negara dengan mayoritas penduduknya muslim. Dengan kata lain umat muslim di Indonesia sangat membutuhkan segala sesuatu yang halal.
Termasuk hukum syariah dalam ekonomi Islam.

Agustianto menjelaskan bahwa sejarah pergerakan ekonomi Islam di Indonesia telah berlangsung sejak tahun 1911, yaitu sejak berdirinya organisasi Syarikat Dagang Islam yang dibidangi oleh para entrepreneur dan para tokoh Muslim saat itu. "Artinya ekonomi Islam sudah di jalankan sejak jaman itu," kata dia.

Melihat perkembangan ekonomi syariah saat ini, dapat dikatakan adalah cerminan dan kerinduan umat Islam Indonesia untuk kembali menghidupkan semangat para entrepreneur muslim masa silam dalam dunia bisnis dan perdagangan, sebagaimana juga menjadi ajaran Nabi Muhammad SAW dan sunah yang diteladankannya kepada umatnya.

"Dalam masa yang panjang peran umat Islam dalam dunia bisnis dan perdagangan di Indonesia cenderung termarginalkan.Perkembangan ekonomi Islam di Indonesia mulai mendapatkan momentumnya untuk tumbuh kembali, baru beberapa tahun belakangan ini," kata dia.

Ekonomi syariah tumbuh kembali semenjak didirikannya Bank Muamalat Indonesia pada tahun 1992, setelah mendapat legitimasi legal formal dengan berlakunya Undang-Undang Nomor 7 Tahun 1992 tentang Perbankan.Dua tahun setelah BMI berdiri, lahir pula Asuransi Syariah Takaful di tahun 1994.Berbarengan dengan itu, tumbuh pula 78 BPR Syariah.Pada tahun 1996 berkembang pula lembaga keuangan mikro syariah BMT.

Namun sayangnya, Lembaga Perguruan Tinggi yang mengajarkan ekonomi syariah masih sangat langka. Tercatat, IAINSU Medan menjadi Perguruan Tinggi pertama di Indonesia yang membuka Program Studi D3 Manajemen Bank Syari'ah sebagai hasil kerja Forum Kajian Ekonomi dan Bank Islam (FKEBI) yang lahir tahun 1990 sebagai realisasi kerja sama dengan IIUM Malaysia.

Agustianto menjelaskan, perkembangan ekonomi syariah dalam bentuk lembaga perbankan dan keuangan syariah memang menunjukkan perkembangannya yang sangat pesat. Orang yang akan 
melakukan ekonomi syariah sudah dapat dengan mudah didukung oleh lembagalembaga perekonomian Islam seperti Perbankan Syariah, Asuransi Syariah, Pasar Modal Syariah, Reksadana Syariah, Obligasi Syariah, Leasing Syariah, Bank Pembiayaan Rakyat Syariah, Baitul Mal wat Tamwil, Koperasi Syariah, Pegadaian Syariah, Dana Pensiun Syariah, lembaga keuangan publik Islam seperti Lembaga Pengelola Zakat dan Lembaga Pengelola Wakaf serta berbagai bentuk bisnis syariah lainnya.

Namun sayangnya, meskipun perkembangan lembaga perbankan dan keuangan syariah demikian cepat, namun dari sisi hukum atau peraturan perundangundangan yang mengaturnya masih jauh tertinggal, termasuk hukum-hukum yang berkaitan dengan penyelesaian sengketa bisnis (hukum dagang) syariah.

"Padahal secara yuridis, penerapan hukum ekonomi syariah di Indonesia memiliki dasar hukum yang sangat kuat," katanya.Dengan perkembangan ekonomi global dan semakin meningkatnya minat masyarakat terhadap ekonomi dan perbankan Islam, ekonomi Islam menghadapi berbagai permasalahan dan tantangan-tantangan yang besar.

Ada lima problem dan tantangan yang dihadapi ekonomi Islam saat ini, pertama, masih minimnya pakar ekonomi Islam berkualitas yang menguasai ilmu-ilmu ekonomi modern dan ilmu-ilmu syariah secara integratif. Kedua, ujian atas kredibilitas sistem ekonomi dan keuangannya, ketiga, perangkat peraturan, hukum dan kebijakan, baik dalam skala nasional maupun internasional masih belum memadai. Keempat, masih terbatasnya perguruan Tinggi yang mengajarkan ekonomi Islam dan masih minimnya lembaga tranining dan consulting dalam bidang ini, sehingga SDI di bidang ekonomi dan keuangan syariah masih terbatas dan belum memiliki pengetahuan ekonomi syariah yang memadai. Kelima, peran pemerintah baik eksekutif maupun legislatif, masih rendah terhadap pengembangan ekonomi syariah, karena kurangnya pemahaman dan pengetahuan mereka tentang ilmu ekonomi Islam.

Penerapan kembali ekonomi syariah di Indonesia maka yang sangat perlu diperhatikan adalah peranan pemerintah yang tidak hanya memperhatikan segi regulasi dan legal formal saja, tetapi juga keberpihakan yang riil kepada lembaga perbankan dan keuangan syari'ah dalam kebijakan ekonomi dan pembangunan.

Misalnya, seperti suntikan modal, pembiayaan proyek pembangunan, tabungan dan setoran haji, pendirian Asuransi dan Bank BUMN Syariah. Selain itu, ekonomi syariah, tidak hanya bisa bergantung pada lembaga keuangan syariah itu sendiri, tidak juga hanya bergantung pada peran pakar seperti IAEI (Ikatan Ahli Ekonomi Islam), tetapi semua stakeholder yang harus bekerja sama dengan pemerintah.

\section{KESIMPULAN}

Dari uraian-uraian yang ada di atas, maka dapat diambil kesimpulan, bahwa sistem ekonomi Islam sebagai sistem ekonomi alternatif sudah dibuktikan dengan adanya kemajuan bank syariah meskipun perkembangannya lambat, karena terkendala banyak hal antara lain permodalan yang minim, peraturan yang belum sampai aplikatif riil, sumber daya manusia, pemahaman umat yang rendah, sosialisasi belum maksimal, piranti moneter yang digunakan negara masih menggunakan bunga, jaringan kantor yang terbatas, dan pelayanan yang belum dapat memenuhi standar seperti yang dilakukan bank-bank konvensional. Akan tetapi sistem ekonomi Islam telah membantu dalam memperkuat pembangunan ekonomi bangsa dan negara terutama saat krisis terjadi tahun 1998 sampai saat ini. 


\section{DAFTAR PUSTAKA}

Hasbi Ash Shiddieqy. (2011). Ekonomi Syariah adalah EkonomiUniversal.

Saidus, Syahar. (1996). Asas-Asas Hukum Islam. Bandung

Tho'in, M. (2011). Pengaruh Faktor-faktor Kualitas Jasa terhadap Kepuasan Nasabah di Baitul Mal Wat Tamwil (BMT) Tekun Karanggede Boyolali. MUQTASID Jurnal Ekonomi dan Perbankan Syariah, 2(1), 73-89.

Tho'in, M. (2015). Konsep Ekonomi Islam Jalan Tengah (KapitalisSosialis). Jurnal Ilmiah Ekonomi Islam, 1(03).

Undang-Undang No. 7 Tahun 1992

Undang-undang Nomor 10 Tahun 1998

Undang-undang Nomor 23 Tahun 1999

Undang-Undang Republik Indonesia Nomor 21 Tahun 2008 Tentang Perbankan Syariah.

Wardani, H. K., \& Tho'in, M. (2013). Pengelolaan Baitul Maal Dalam Meningkatkan Kesejahteraan Negara. Jurnal Akuntansi dan Pajak, 14(01).

Wardani, H. K. (2015). Perilaku Riba Kebiasaan Masyarakat Sesat Tidak Sesuai Prinsip-Prinsip Syariah Islam. Jurnal Ilmiah Ekonomi Islam, 3(02), 152-156. 